\title{
EXPERT TECHNOLOGY FOR RISK MANAGEMENT IN THE IMPLEMENTATION OF QRM IN A HIGH-TECH INDUSTRIAL ENTERPRISE
}

\author{
Nikolay AKATOV, Zhanna MINGALEVA \\ Perm National Research Polytechnic University \\ Ivana KLAČKOVÁ \\ University of Zilina \\ Gulnara GALIEVA \\ PJSC «Perm Scientific-Industrial Instrument Making Company \\ Nataliy SHAIDUROVA \\ Votkinsky branch of FGBOU VO \\ Izhevsk State Technical University named after MT Kalashnikov
}

\begin{abstract}
:
In modern conditions, management technology is becoming the main instrument of competition in many areas of production and business. The article focuses on the examinations of issues related to the possibilities of introducing an integrated risk management system in modern high-tech enterprises. The main scientific research methods are bibliographic analysis, formal logic methods, comparative analysis, methods of analogies. Based on the application of the guidelines of systems' theory, of the theory of self-organization, the theory of risk management, and the theory of reflexive control the expert technology for risk management in a hightech industrial enterprise was developed. As a result of the study, it was revealed that the use of technologies such as the ETRM will help to increase the feasibility and effectiveness of implementing complex projects such as fast-response QRM production.
\end{abstract}

Key words: effective management technology, risk management, QRM production

\section{INTRODUCTION}

The need for an expert technology for risk management (ETRM) is growing as the external environment for hightech industrial enterprises (HTIEs) becomes more uncertain.

In modern conditions, management technology is becoming the main instrument of competition in many areas of production and business. Management activity is more effective the more its essential properties correspond to the essential properties of technology: operational efficiency, profitability, modernity, integrability, integrity, self-sufficiency of management methods, transformative nature, guarantee of achievement and reproducibility of results. If all interconnected management procedures acquire the properties of technology, then this turns it into the main source of competitive advantages of the company and into the basic condition for the possibility of management transition to a new stage of development. Therefore, the development of methods of creating new management technologies that take into account current trends in the development of science and technology, as well as changes in socio-economic processes, is becoming one of the key management functions. Successful examples of such technologies already exist, for instance, the theory of solving inventive problems (TRIZ), artificial intelligence, Big Date, etc. With regard to the field of risk management in high-tech enterprises, the development of such technologies is turning into a leading aspect of managerial activity.

\section{LITERATURE REVIEW}

The term "management technology", "management approaches", "reflexivity" and "reflective practice" in terms of technology are a fairly common phenomenon in modern management. Confirmation of this is the presence of special sections in leading scientific journals and monographs on management (for instance, "Productive reflection at work". Oxon: Routledge, 2006) and independent journals (for instance, "Reflective Practice"). The most famous works of such researchers as M. Alvesson, M.S. 
Archer, R.J. Cotter, J.G. Cullen, R. Edwards, D.E. Gray, C. Hardy, A.I. Prigozhin, N. Phillips, E.A. Smirnov, V.N. Usov and others.

Hardy C., Phillips N. and Clegg S.R. conducted a detailed analysis of reflexivity issues in organization and management theory [20]. M. Alvesson and colleagues devote their research to reflective methodology [1, 2, 3]. H.K. Adriansen and $\mathrm{H}$. Knudsen investigated the most effective ways of training managers to perform an indefinite role based on reflexivity [4]. M.S. Archer is studying the reflexive imperative in late modernity [5], the human reflexivity and social mobility [6]. The relationship between social and economic modernization and relational reflexivity was studied in the works of P. Donati [12].

At different times, R. Edwards [13], J.K. Barge [7], M. Eraut [14], R.J. Cotter [8, 9], T. Fenwick [17], S. Halford, P. Leonard [19] and others showed the importance of flexibility, reflexivity and reflection. Cunliffe 's works reveal the dynamical process from reflection to practical reflexivity [10, 11]. An analysis of the formation of leadership qualities with the help of reflexivity is presented by M. Eriksen [15]. And ways of developing critical thinking of managers with the help of reflective tools are proposed in the work of D.E. Gray [18].

In Russian modern approaches to organization and management theory, reflection and reflexive management rightly claim priority consideration when studying the role of the subject of management in the implementation of the risk management process $[25,26,29]$. And first of all because "reflection" acquired many meanings, retaining an essential attribute in the course of its study and application. Reflection is "a type of philosophical thinking aimed at comprehending and substantiating one's own premises, requiring the conversion of consciousness to oneself" $[26,27,30]$. Based on this V.N. Usov believes that "management activities carried out on the basis of reflection and through reflection are defined in various forms as reflective management" $[17,27,28]$. It should also be emphasized that concentration in the understanding of reflection as "primarily thinking" and its separation from the "activity itself" can create a mental gap that impedes its application in practice. In reality, reflection is "both thinking and action at the same time. And more precisely, it turns out to be thought-action" [18, 21, 31]. A comprehensive and comprehensive understanding of reflection in the theory of organization and management is given in the works of A.I. Prigozhin [22, 23].

Based on the bibliographic analysis, a shift in emphasis was identified in modern risk management models with the use of separate approaches and risk management methods towards integrated technologies. Such complex technologies are applied simultaneously to several interconnected and interacting heterogeneous processes of a technological, economic, organizational, socio-psychological nature. Thus, the leading aspect of managerial technology is not only cognitive, but actually managerial, aimed at the generation and self-reproduction of new managerial technologies.

\section{METHODOLOGY}

The theoretical foundations of the study are the provisions of systems' theory, of the theory of self-organization, the theory of risk management, and the theory of reflexive control. The research methodology includes the integrated application of the principles and methods of these theories.

The formation of the ETRM model is based on a number of methodological principles of the theory of complex systems' control.

1. Recognition of an increasingly higher degree of uniqueness (specificity) of a modern high-tech enterprise.

2. Recognition of the increasing complexity of the control object and tasks.

3. Recognition of an ever-increasing level of uncertainty and irreversibility of processes, high dynamism and the need for a quick reaction to changes.

4. Recognition of multicriteria and incompleteness, fuzziness of initial information for decision making, including fuzzy wording of achieved goals.

Those risk managers who use these methodological principles of system theory can develop a position that allows them to cope with modern challenges and choose solutions that will help to maintain the required level of enterprise competitiveness. In theory, this means a transition from the traditional logic of creating systems for supporting management decisions to the logic of supporting the activities of senior decision-makers. In practice, this means a transition to a set of decision-making rules specific to active systems.

It is taken into account in the research process that the sphere of risk management is characterized by the properties of uncertainty and situationality. These properties generate factors, the identification of which, as well as the response to them is included in the job descriptions of employees [4]. With a passive attitude of workers, newly emerging problems can be revealed too late only at a higher level or go to the base of hidden ("masked") dangers. Therefore, management methods that allow transferring managerial influence under conditions of uncertainty and the absence of strict administration are very important for high-tech enterprises. Awareness of the exceptional role of reflective control in solving such problems of a high level of complexity becomes a key priority. Methodological approaches of the theory of reflexive control and the theory of self-organization were used to solve the following research problems:

1) substantiation of the need to move from the traditional stage of the search for reasons to the stage of self-determination of the subject of management when developing a risk management mechanism at the enterprise. A clear initial record of the responsibility of the decision maker and the person who takes responsibility for their implementation is necessary for such a transition;

2) specification of the reflective position, i.e. a description of the position with which senior management looks at a high-tech industrial enterprise, and how it displays this activity; 
3) the transition from individual expert assessments of a particular measurement object to expert technologies that implement the development of procedures that include all stages of the technological process of formalizing expert information, its collection and analysis based on information technology and intelligent management tools.

Thus, the development of the expert technology for risk management (ETRM) includes a "social context", which is understood as norms, artifacts, structures, processes and institutions, in the context of which behavior is demonstrated and reproduced.

\section{RESEARCH RESULTS}

As a result of the study, it was revealed that the process of reflection can be represented by the following procedures: "pause, fixation, removal, objectification, wrapping" (Figure 1).

Based on the reflection algorithm presented in Figure 1, a cycle of reflective enterprise development management is implemented, during which a transition to a new level of organization is carried out. At the same time, the need to technologicalize the reflexive process, which reflects the very essence of reflection as the ability of a system to build models of itself and other systems, and at the same time see itself building such models, is being updated.

\begin{tabular}{|c|c|c|c|c|}
\hline \multicolumn{5}{|c|}{ Pause } \\
\hline \multicolumn{2}{|c|}{$\begin{array}{c}\text { The cessation of } \\
\text { substantive activities in a } \\
\text { situation determined by } \\
\text { management }\end{array}$} & \multicolumn{2}{|c|}{$\begin{array}{c}\text { The situation is defined as the need } \\
\text { for an answer to a set of questions } \\
\text { related to the development of the } \\
\text { organization }\end{array}$} & $\begin{array}{l}\text { Exit from active current } \\
\text { activities and taking a } \\
\text { position "outside" and } \\
\text { "above" the situation }\end{array}$ \\
\hline \multicolumn{5}{|c|}{ Fixation } \\
\hline \multicolumn{3}{|c|}{$\begin{array}{l}\text { Formation of the image of activity (for } \\
\text { example, business models) }\end{array}$} & \multicolumn{2}{|c|}{$\begin{array}{l}\text { The competence of management to reflect } \\
\text { their actions in an arbitrary situation in } \\
\text { the context of formed needs }\end{array}$} \\
\hline \multicolumn{5}{|c|}{ Removal } \\
\hline \multicolumn{3}{|c|}{$\begin{array}{c}\text { Understanding the process of "I acting" in } \\
\text { a busy reflective position }\end{array}$} & \multicolumn{2}{|c|}{$\begin{array}{l}\text { Analysis of the adequacy of the formed } \\
\text { look of activity (models and ideas), the } \\
\text { formation of judgments about its } \\
\text { adequacy }\end{array}$} \\
\hline \multicolumn{5}{|c|}{ Objectification } \\
\hline $\begin{array}{l}\text { Assessment of own } \\
\text { actions in the } \\
\text { system of existing } \\
\text { conditions and } \\
\text { restrictions } \\
\end{array}$ & $\begin{array}{r}\mathrm{R} \\
\mathrm{recc} \\
\text { const } \\
\mathrm{ac}\end{array}$ & $\begin{array}{l}\text { etrospective } \\
\text { nstruction and } \\
\text { ruction of future } \\
\text { tivity models }\end{array}$ & $\begin{array}{c}\text { Identification and } \\
\text { understanding of } \\
\text { other promising } \\
\text { models of activity }\end{array}$ & $\begin{array}{l}\text { The formation of its } \\
\text { updated position as a } \\
\text { subject of activity } \\
\text { (self-determination) }\end{array}$ \\
\hline \multicolumn{5}{|c|}{ Turn round } \\
\hline \multicolumn{3}{|c|}{$\begin{array}{l}\text { Reflexive return as an act of returning to } \\
\text { meaningful activity, but with a new } \\
\text { position and new opportunities }\end{array}$} & \multicolumn{2}{|c|}{$\begin{array}{l}\text { Initiation and implementation of changes } \\
\text { (self-initiation) }\end{array}$} \\
\hline
\end{tabular}

Fig. 1 Universal reflection algorithm in the management of a high-tech industrial enterprise

Figure 2 shows a set of interconnected expert risk management tasks solved by a distributed risk management group.

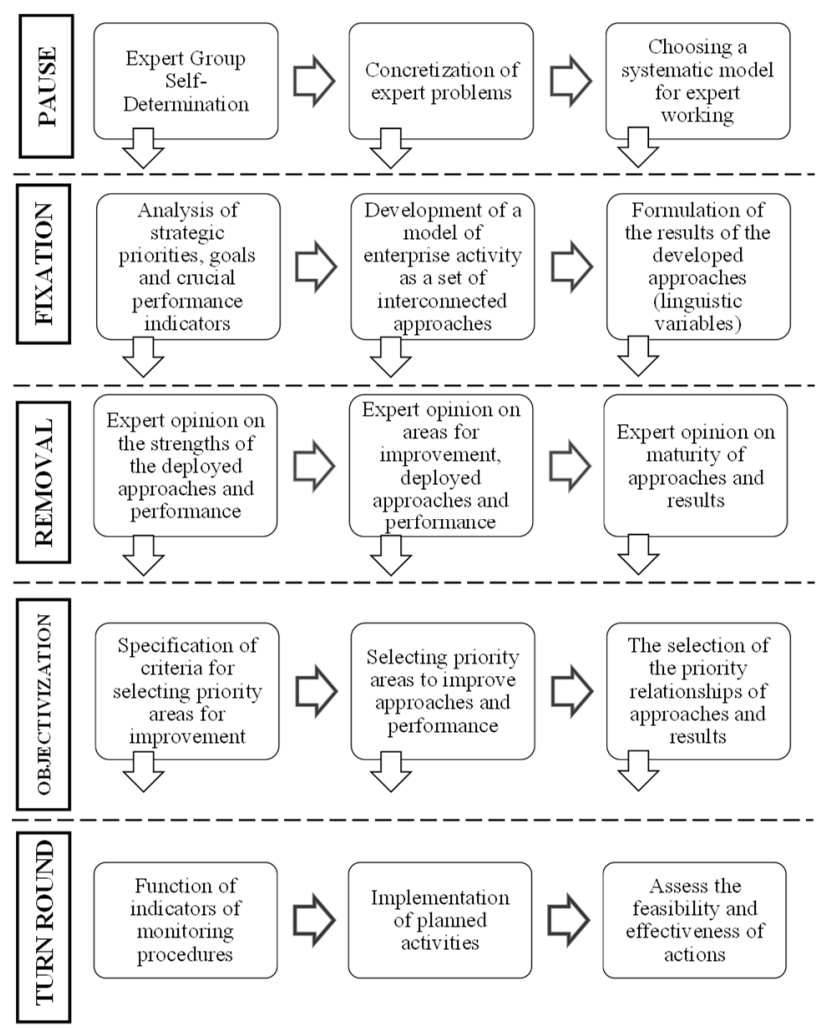

Fig. 2 Interconnected expert tasks and the results of their solution within the framework of expert technology for risk management

At the first stage of the implementation of the URTS model, the self-determination of the subject of management is carried out - the formation of an expert group, which should include representatives of the top management of the enterprise, the project manager of QRM, the institute of supervisors QRM, the curator of QRM, leaders and specialists of QRM cells, etc. Tasks are formulated for the management subject, to create a space for self-diagnosis of activities and make changes to activities in the context of the QRM implementation strategy, ensuring and maintaining an appropriate level of risk. Providing and maintaining an appropriate level of risk is the target function of the sequence of procedures of expert risk management technology (ETRM).

The purpose of introducing ETRM is the appropriate rationalization of the process, its rationalization by eliminating activities and operations that are not necessary to solve the task and achieve a result and ensure high interconnectedness of actions. Thus, the proposed scheme and algorithm should act as a well-coordinated mechanism, which presents the manager with both a general picture and the ability to analyze individual aspects.

\section{CONCLUSION}

Focusing on the problems of using integrated risk management mechanisms, as a way to increase guarantees to achieve the goals of implementing QRM in high-tech industrial enterprises, has actualized the key problem associated with the involvement of personnel in risk-taking decisions. 
The result was the formulation of a sequence of actions to involve personnel in the full cycle of development and implementation of risk decisions. This sequence of actions, ensuring the involvement of personnel in expert work on the early identification and analysis of risk situations, in learning by action to develop and implement measures to respond to risks and create incentive conditions for taking more personal responsibility for achieving goals, we presented as ETRM, implemented within reflective management cycle.

The ETRM model is not just the technologicalization of certain stages. It is a new type of technology designed to create an environment of active participation of the personnel of the high-tech industrial enterprise. The main idea is that it is adapted to solve problems related to staff involvement, with its direct active participation in developing solutions. The technology is adapted to create and maintain an environment of active inclusion and involvement of the personnel of the high-tech industrial enterprise in the decision-making process. The staff at ETRM acts as an expert who takes responsibility for the implementation of the decision.

The use of technologies such as the ETRM will help to increase the feasibility and effectiveness of implementing complex projects such as fast-response QRM production. The proposed "Expert Technology for Risk Management in the Implementation of QRM" refers to integrated technologies along with integrated technologies such as Total Quality Management (TQM) technology, company market behavior technology and restructuring technology. The development of ETRM was based on the allocation of new priority areas for the development of the sphere of economics and management, the inclusion of the latest achievements in these areas in management technologies. In developing the ETRM, a modern understanding of the diverse aspects of the behavior of the control object, manifested as a "social action", which means the form, content and results of individual and group behavior, was taken into account.

The scientific results presented in the article create a methodological basis for the targeted actions of the modern management of high-tech enterprises that implement the strategy of creating QRM productions. At the same time, the conceptual model of ETRM may well be considered by organizations in other fields of activity for the purpose of managing the transition to organizations of a new type, based on the involvement of the potential of selfdevelopment.

\section{ACKNOWLEGEMENT}

The work is carried out on the basis of the task of the Ministry of Education and Science of the Russian Federation to Perm National Research Polytechnic University (the topic \# 26.6884.2017/8.9 "Sustainable development of urban areas and the improvement of the human environment". This article was made umder the support of APVV project - APVV16-0283. Project title: Research and development of multicriteria diagnosis of production machinery and equipment based on the implementation of artificial intelligence methods.

\section{REFERENCES}

[1] M. Alvesson, C. Hardy, B. Harley. "Reflecting on reflexivity: Reflexive textual practices in organisation and management theory". Journal of Management Studies, 2008, vol.45, no 3, pp. 480-501.

[2] M. Alvesson, J. Sandberg. "Has management studies lost its way? Ideas for more imaginative and innovative research". Journal of Management Studies, 2013, vol. 50, no 1, pp. 128-152.

[3] M. Alvesson, K. Skoldberg. Reflexive methodology: New vista's for qualitative research. London: Sage, 2009.

[4] H. K. Adriansen, H. Knudsen. "Two ways to support reflexivity: Teaching managers to fulfil an undefined role". Teaching Public Administration, 2013, vol.31, no 1, pp. 108-123.

[5] M. S. Archer. Making our way through the world: Human reflexivity and social mobility. Cambridge: Cambridge University Press, 2007.

[6] M. S. Archer. The reflexive imperative in late modernity. Cambridge: Cambridge University Press. 2012.

[7] J. K. Barge. "Reflexivity and managerial practice". Communication Monographs, 2004, vol. 71, no 1, pp. 70-96.

[8] R. J. Cotter. "Reflexive spaces of appearance: Rethinking critical reflection in the workplace". Human Resource Development International, 2014, vol. 17, no 4, pp. 1-16.

[9] R. J. Cotter, J. G. Cullen. "Reflexive management learning: An integrative review and a conceptual typology". Human Resource Development Review, 2012, vol. 11, no 2, pp. 227-253.

[10] T. Dodok, N. Cubonova, M. Cisar, I. Kuric, I. Zajacko. “Utilization of strategies to generate and optimize machining sequences in CAD/CAM". $12^{\text {th }}$ International Scientific Conference of Young Scientists on Sustainable, Modern and Safe Transport, Slovakia, 31.05-02.06.2017, vol. 192, pp. 113-118

[11] A. L. Cunliffe. "Reflexivity, learning and reflexive practice" in The Sage handbook of management learning, education and development, London: Sage, 2009, pp. 405-419.

[12] A. L. Cunliffe, M. Easterby-Smith. "From reflection to practical reflexivity: Experiential learning as lived experience" in: Organising reflection. Hampshire: Ashgate, 2004, pp. 30-47.

[13] P. Donati. "Modernization and relational reflexivity", International Review of Sociology, 2011, vol. 21, no 1, pp. 2139.

[14] R. Edwards. "Flexibility, reflexivity and reflection in the contemporary workplace". International Journal of Lifelong Education, 1998, vol.17, no 6, pp. 377-388.

[14] M. Eraut. "Informal learning in the workplace". Studies in Continuing Education, 2004, vol. 26, no 2, pp. 247-273.

[15] M. Eriksen. "Authentic leadership: Practical reflexivity, self-awareness, and selfauthorship". Journal of Management Education, 2009, vol. 33, no 6, pp.747-771.

[16] P. Erlandson. "Giving up the ghost: The control-matrix and reflection-in-action", Reflective Practice, 2006. Vol.7, no1, pp. 115-124.

[17] T. Fenwick. "Tides of change: New themes and questions in workplace learning". New Directions for Adult and Continuing Education, 2001, vol. 92, pp. 3-18.

[18] D. E. Gray. "Facilitating management learning: Developing critical reflection through reflective tools". Management Learning, 2007, vol.38, no 5, pp. 495-571. 
[19] S. Halford, P. Leonard. "Place, space and time: Contextualising workplace subjectivities". Organisation Studies, 2006, vol.27, no 5, pp. 657-676.

[20] I. Kuric. "New methods and trends in product development and planning". $1^{\text {st }}$ International Conference on Quality and Innovation in Engineering and Management (QIEM). Cluj Napoca, 17.3.-19.3. pages: 453-456, published: 2011, ISBN:978-973-662-614-2

[21] B. Bako, P. Božek. "Trends in simulation and planning of manufacturing companies". ICMEM 2016, Procedia Engineering Volume 149, Pages 571-575

[22] S.V. Komarov, S.I. Cordon. Basics of the methodology: systematic approach. Categories. Perm: Publishing House Perms state University, 2005. 384 p.

[23] A. I. Prigozhin. Disorganization: Reasons, types, overcoming. M, Alpina Business Books, 2007, 402 p.

[24] A. I. Prigozhin. "Business macroculture: development methods". Social sciences and modernity, 2017, no. 1, pp. 114127.

[25] P. Božek, P. Pokorný. "Analysis and evaluation of differences dimensional products of production system". In Applied Mechanics and Materials, Volume 611, 2014, Pages 339-345.

\section{Nikolay Akatov \\ ORCID ID: 0000-0002-4272-1055}

Perm National Research Polytechnic University

Komsomolsky prospect, 29, Perm, 614990, Russian Federation

e-mail: alex@rmc.edu.ru

\section{Ivana Klačková}

University of Zilina, The Faculty of Mechanical Engineering Department of Automation and Production Systems Univerzitna 8215/1, 01026 Zilina, Slovak Republic e-mail: ivana.klackova@fstroj.uniza.sk

\section{Zhanna Mingaleva}

ORCID ID: 0000-0001-7674-7846

Perm National Research Polytechnic University

Komsomolsky prospect, 29, Perm, 614990, Russian Federation

e-mail: mingal1@pstu.ru

\section{Gulnara Galieva}

PJSC «Perm Scientific-Industrial Instrument Making Company» 25 October street, 106, Perm, 614990, Russian Federation e-mail: GalievaGI@pnppk.ru
[26] Z. Ságová, A. Lozkin, I. Klačková. “Calculate the trajectories of mechatronic systems and CAD/CAM". In: $10^{\text {th }}$ International Technical Conference, Technological Forum 2019, 18.-20.6.2019, ISBN 978-80-87583-30-2.

[27] A. Sapietová, M. Sága, I. Kuric, I., et al., Application of optimization algorithms for robot systems designing. International Journal of Advanced Robotic Systems, 2018, ISSN: 1729-8814.

[28] E.A. Smirnov. "Technology of living solutions as a component of instrumental competence of a specialist". University Herald, 2008, no. 3 (24), pp. 63-67.

[29] The latest philosophical dictionary. M., Interpres servis; Book House, 2001. 1280 p.

[30] V. Tlach, M. Cisar, I. Kuric, I. Zajacko. „Determination of the Industrial Robot Positioning Performance". Modern Technologies in Manufacturing (MTEM 2017 - AMATUC), Cluj Napoca, 12.10-13.10.2017, Article number: UNSP 01004

[31] V.N. Usov. "Reflexive management: philosophical - methodological aspect." PhD thesis, Yekaterinburg, 2008.

\section{Nataliy Shaidurova}

Votkinsky branch of FGBOU VO "Izhevsk state technical university named after MT Kalashnikov", Votkinsk, Russian Federation e-mail: Shaydurovans@gmail.com 